\title{
Analysis of Aggressiveness of Erwinia amylovora Using Disease-Dose and Time Relationships
}

\author{
Jordi Cabrefiga and Emilio Montesinos
}

Institute of Food and Agricultural Technology-CIDSAV-CeRTA, University of Girona, Campus Montilivi, 17071, Girona, Spain. Accepted for publication 10 August 2005.

\begin{abstract}
Cabrefiga, J., and Montesinos, E. 2005. Analysis of aggressiveness of Erwinia amylovora using disease-dose and time relationships. Phytopathology 95:1430-1437.

The aggressiveness of an extensive collection of strains of Erwinia amylovora was analyzed using immature fruit and detached pear flower assays under controlled environmental conditions. The analysis was performed by means of a quantitative approach based on fitting data to mathematical models that relate infection incidence to pathogen dose and time. Probit and hyperbolic saturation models were used for disease-dose relationships and provided information on the median effective dose $\left(\mathrm{ED}_{50}\right)$. Values of $\mathrm{ED}_{50}$ ranged from $10^{3}$ to $10^{6} \mathrm{CFU} / \mathrm{ml}\left(10\right.$ to $10^{4} \mathrm{CFU}$ per site of inoculation). A modified Gompertz model was used for disease-time relationships and provided information on the rate of infection incidence progression $\left(r_{g}\right)$ and time delayed to start of the incidence

progress curve $\left(t_{0}\right)$. Values of $r_{g}$ ranged from near 0 to 1.90 , and $t_{0}$ varied from 1.3 to more than 10 days. The more aggressive strains showed high $r_{s}$, low $\mathrm{ED}_{50}$ values, and short $t_{0}$, whereas the less aggressive strains showed low $r_{g}$, high $\mathrm{ED}_{50}$, and long $t_{0}$. The aggressiveness was dependent on plant material type and pear cultivars and was significantly different between strains of E. amylovora. Infectivity titration and kinetic analysis of progression of incidence of infections using the immature pear test and a standardized scale are proposed for assessment of strain aggressiveness. The implications of $r_{g}, \mathrm{ED}_{50}$, and $t_{0}$ for the epidemiology and management of fire blight are discussed, particularly the wide range of aggressiveness among strains, the degree of host specificity observed in pear isolates, the very high infective potential of this pathogen, the independent action of pathogen cells during infection, and the possible advantage of including aggressiveness parameters into fire blight risk forecasting systems.
\end{abstract}

Fire blight of rosaceous plants caused by Erwinia amylovora is an economically important disease that affects mainly apple and pear production and several woody ornamental plants worldwide $(53,55)$. The disease has spread to new regions in recent years $(11,19,24,52)$ and its control is difficult $(45,53-55)$.

Knowledge of the variability in pathogenicity of $E$. amylovora is important for disease management and epidemiology because it may give information about the evolutionary potential of this pathogen in terms of durability of cultivar resistance and of control methods (e.g., biological control). However, there is a considerable lack of consensus among plant pathologists about terms and concepts related to pathogenicity. Pathogenicity has been defined as the overall ability of a pathogen to infect a host and cause disease $(10,46)$. According to Shaner et al. (46), the components of pathogenicity are virulence and parasitic fitness, whereas Boss and Parlevliet (10) considered pathogenicity to be composed of virulence and aggressiveness. Some authors refer to virulence as a qualitative attribute of pathogenicity $(1,10)$ or the capacity of a pathogen to cause disease as a result of the expression of genetic determinants or virulence factors in the host-pathogen interaction (e.g., virulent or nonvirulent). Parasitic fitness refers to the success of the pathogen within a population (e.g., reproductive fitness, dispersal capacity) (1), whereas aggressiveness is considered quantitative and refers to the intensity of disease or attack produced by a pathogen $(10,46)$. Accordingly, with these concepts, the present study deals with aggressiveness in E. amylovora.

Aggressiveness can be measured in terms of the progression of infections, migration of pathogen cells from the point of inoculation, amount of pathogen inoculum needed to produce a given

Corresponding author: E. Montesinos; E-mail address: emonte@ @intea.udg.es

DOI: 10.1094/PHYTO-95-1430

(C) 2005 The American Phytopathological Society effect on host, or rate of disease progression. Several studies have been performed to analyze the variability in aggressiveness among strains of E. amylovora. Some reports have been unable to observe significant differences in aggressiveness among strains $(25,39)$, whereas others $(17,33-36,45)$ have observed them. This lack of agreement may be due to the composition of the strain collection studied, but also to differences between studies in the methods of assay used to measure aggressiveness, plant material, dose of pathogen, or time of disease assessment after pathogen inoculation.

Methods of analysis used to study aggressiveness in E. amylovora include inoculation of the pathogen to whole plants or in vitro micropropagated plant material, and monitoring the progression of infections or the migration from the point of inoculation $(8,34,35,50)$. However, ex vivo alternative methods, originally developed for screening large amounts of biological control agents of fire blight, such as the immature pear fruit (3) and the crab apple blossom assays $(37,38)$, can be useful and have not been tested for assessment of aggressiveness in an extensive collection of strains.

The analysis of aggressiveness is influenced by the dose of pathogen inoculated and the time at which disease is evaluated. The effect of pathogen concentration on disease was first studied by Ercolani and Van der Plank $(15,51)$ and, later, models to relate disease levels to the dose of pathogen, and tools to fit data and derive aggressiveness parameters (e.g., median effective dose) were developed and tested in several fungal and bacterial plant pathogens $(16,20,31,42,43,47)$. However, disease-dose relationships have not been used to analyze aggressiveness in E. amylovora. Studies of aggressiveness also are affected by the time at which disease is evaluated after pathogen inoculation. Disease progress curves have been used to compare the susceptibility of apple and pear cultivars to a strain of E. amylovora (30) based on kinetic analysis of disease progression currently used in epidemi- 
ology (12). However, the mathematical equation used did not account for the delay in the start of the disease progress curve which often is observed in weakly virulent strains or hosts with some resistance to E. amylovora.

Several authors consider aggressiveness to be composed of infectiveness and invasiveness $(9,46)$. Infectiveness can be defined as the efficiency of the pathogen inoculum in terms of development of infections and is inversely proportional to the number of pathogen cells required to cause an infection or to kill a susceptible host. It can be estimated as a median effective dose $\left(\mathrm{ED}_{50}\right)$ using infectivity titration experiments (31) in an approach similar to that used in insect (49) and clinical microbiology (13). Invasiveness can be defined as the capacity of a pathogen to grow and spread within the host, and it can be estimated as a rate of disease progression using kinetic analysis of infection incidence. Analysis of infectiveness and invasiveness in representative strains of E. amylovora may provide useful information for understanding the epidemiology and management of fire blight.

The objective of the present work was to analyze aggressiveness in E. amylovora by estimating the $\mathrm{ED}_{50}$ and the rate of progression of infection incidence $\left(r_{g}\right)$ in an extensive collection of pathogen strains isolated from fire blight outbreaks in Spain and reference strains from different areas of geographical origin.

\section{MATERIALS AND METHODS}

Bacterial strains and inoculum preparation. Thirty-six E. amylovora strains were used in the present study (Table 1). The strains were selected for their variety regarding different host plants and geographical origin. Twenty-five strains originally were isolated from outbreaks detected in Spain since the first introduction of fire blight in 1995. The remaining 11 strains originated from different parts of the world and were used as reference strains in this study. Strains were confirmed as E. amylovora based on various criteria, including their growth characteristics in several culture media (sucrose nutrient agar [7], Miller-Schroth agar [27], and $\mathrm{MM} 2 \mathrm{Cu}$ agar [5]), double-antibody sandwich indirect enzyme-linked-immunosorbent assay (18), polymerase chain reaction (PCR) directed to pEA29 plasmid (6) and to ams gene (4), and pathogenicity on immature pear fruit (3). Cultures were stored in $20 \%$ glycerol at $-80^{\circ} \mathrm{C}$ until use. Bacterial suspensions used for inoculation were obtained from cultures grown overnight at $25^{\circ} \mathrm{C}$ on Luria-Bertani agar. For the preparation of suspensions, the cells were scraped from the agar surface and suspended in sterile distilled water. The cell concentration was adjusted by dilution to $10^{8} \mathrm{CFU} / \mathrm{ml}$ using a previously prepared viable-absorbance relationship. Because this relationship was found not significantly different among several strains tested, a standard calibration curve was used for the 36 strains studied. The original suspension was 10 -fold serial diluted in sterile distilled water to obtain concentrations of $10^{7}, 10^{6}, 10^{5}, 10^{4}, 10^{3}$, and $10^{2} \mathrm{CFU} / \mathrm{ml}$.

Immature pear fruit tests. The immature pear fruit assay was based on a method previously described for screening biological control agents of fire blight (3), but was modified in the present work to use whole fruit instead of pear halves. Immature pear

TABLE 1. Origin and year of isolation of Erwinia amylovora strains used in this work ${ }^{\mathrm{Z}}$

\begin{tabular}{|c|c|c|c|c|}
\hline Strain & Host plant & Source & Country & Year of isolation \\
\hline CFBP1430 & Crataegus sp. & CFBP & France & 1972 \\
\hline PMV6076 & Crataegus sp. & PMV & France & 1990 \\
\hline $\mathrm{Ea} 273$ & Malus sylvestris & CUCM & United States & 1971 \\
\hline 115.22 & Cydonia oblonga & $\ldots$ & Bulgary & 1989 \\
\hline EPS 100 & Pyrus malus & This study & Girona (Spain) & 1997 \\
\hline EPS101 & Pyrus communis & This study & Lleida (Spain) & 1999 \\
\hline IVIA1614.2 & Pyracantha sp. & IVIA & Segovia (Spain) & 1996 \\
\hline NCPPB1734 & Pyrus communis & NCPPB & Egypt & 1965 \\
\hline NCPPB1819 & Crataegus sp. & NCPPB & United States & 1966 \\
\hline NCPPB2080 & P. communis & NCPPB & New Zealand & 1968 \\
\hline NCPPB311 & P. communis & NCPPB & Canada & 1952 \\
\hline NCPPB3159 & Malus sylvestris & NCPPB & Netherlands & 1981 \\
\hline NCPPB595 & P. communis & NCPPB & England & 1958 \\
\hline NCPPB683 & P. communis & NCPPB & England & 1959 \\
\hline SIA1 & P. communis & SIA & Zaragoza (Spain) & 2000 \\
\hline SIA13 & P. communis & SIA & Zaragoza (Spain) & 2000 \\
\hline SIA7 & P. communis & SIA & Zaragoza (Spain) & 2000 \\
\hline SV1000 & P. communis & SV-DARP & Lleida (Spain) & 1999 \\
\hline SV2773 & P. communis & SV-DARP & Lleida (Spain) & 1999 \\
\hline SV4300 & P. communis & SV-DARP & Lleida (Spain) & 1999 \\
\hline SV4320 & P. communis & SV-DARP & Lleida (Spain) & 1999 \\
\hline SV4408 & P. communis & SV-DARP & Lleida (Spain) & 1999 \\
\hline SV4499 & P. communis & SV-DARP & Lleida (Spain) & 1999 \\
\hline SV4500 & P. communis & SV-DARP & Lleida (Spain) & 1999 \\
\hline SV4576 & P. communis & SV-DARP & Lleida (Spain) & 1999 \\
\hline UPN500 & P. communis & UPN & Guipúzcoa (Spain) & 1998 \\
\hline UPN513 & P. communis & UPN & Guipúzcoa (Spain) & 1998 \\
\hline UPN514 & P. communis & UPN & Guipúzcoa (Spain) & 1998 \\
\hline UPN529 & Pyracantha sp. & UPN & Navarra (Spain) & 1997 \\
\hline UPN530 & Pyrus communis & UPN & Navarra (Spain) & 1997 \\
\hline UPN546 & Cydonia sp. & UPN & Navarra (Spain) & 1998 \\
\hline UPN562 & Pyracantha sp. & UPN & Navarra (Spain) & 1998 \\
\hline UPN575 & Pyrus malus & UPN & Navarra (Spain) & 1998 \\
\hline UPN609 & Sorbus sp. & UPN & Navarra (Spain) & 1998 \\
\hline UPN610 & Pyracantha sp. & UPN & Navarra (Spain) & 1998 \\
\hline UPN611 & Cotoneaster sp. & UPN & Navarra (Spain) & 1998 \\
\hline
\end{tabular}

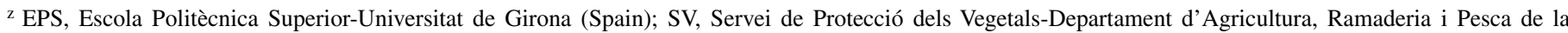
Generalitat de Catalunya (Spain); CUCM, Cornell University Collection of Microorganisms, Ithaca, NY (United States); NCPPB, National Collection of Plant Pathogenic Bacteria, Plant Pathogen Laboratory, Harpenden, Hersfordshire (England); CFBP, Collection Française de Bactèries Phytopathogènes, INRA Angers (France); PMV, Laboratoire de Pathologie Moleculaire et Végétale INRA/INA-PG, Paris (France); IVIA, Instituto Valenciano de Investigacions Agrarias, Valencia (Spain); UPN, Universidad Publica de Navarra, Pamplona (Spain); and SIA, Servicio de Investigaciones Agrarias de Aragón, Zaragoza (Spain). 
fruit were collected from a commercial orchard in early June at the 6-week stage from fruit set, and kept in the dark at 0 to $4^{\circ} \mathrm{C}$. The fruit were used before 1 month of storage to avoid significant physiological changes affecting the assay. Before inoculation, the fruit were surface disinfected by immersion for $1 \mathrm{~min}$ in a diluted solution of sodium hypochlorite ( $1 \%$ active chlorine), washed two times in distilled water, and left under air flow in a sterile cabinet to remove excess water. Each fruit was wounded four times on opposite sides with a needle (approximately $2 \mathrm{~mm}$ in diameter and $5 \mathrm{~mm}$ in depth). Thereafter, $10 \mu \mathrm{l}$ of a suspension of E. amylovora at the suitable concentration was deposited in each wound. Inoculated fruit were placed on polystyrene tray packs which were introduced in plastic boxes and incubated at $21^{\circ} \mathrm{C}$ in a controlled environment chamber. Wounds were considered to be infected when either drops of bacterial exudates or necrosis appeared in and around the point of inoculation of the pathogen.

Detached pear flower tests. The detached pear flower assay was based on the crab apple blossom assay described by Pusey $(37,38)$ for screening biological control agents against fire blight. Detached pear branches, 2 years old, bearing 7 to 15 dormant flower buds were taken from a commercial orchard during winter. Individual pear flowers were obtained from pear branches forced to bloom in an environmental chamber following the procedure described by Montesinos and Vilardell (32). The open blossoms were detached from branches and the individual flowers were maintained with the cut peduncle submerged in $1 \mathrm{ml}$ of $10 \%$ sucrose solution in a single, $1.5-\mathrm{ml}$ plastic Eppendorf vial. Vials were placed in plastic racks and flowers were inoculated by deposition on the hypanthium of $10 \mu \mathrm{l}$ of a pathogen suspension at the corresponding concentration. Then, racks were placed in plastic boxes, covered with plastic bags, and incubated at $21^{\circ} \mathrm{C}$ under moist conditions and $16 \mathrm{~h}$ of fluorescent light and $8 \mathrm{~h}$ of darkness. Flowers were considered to be infected when necrosis was observed in the hypanthium.

Infectivity titration assays. Plant material consisting of detached flowers or fruit of cvs. Conference, Passe Crassane, or Doyenne du Comice were inoculated with strains of E. amylovora (EPS100, NCPPB311, IVIA1614.2, NCPPB595, UPN529, UPN611, and EPS101) at $10^{2}, 10^{3}, 10^{4}, 10^{5}, 10^{6}, 10^{7}$, and $10^{8} \mathrm{CFU} / \mathrm{ml}$. Due to the multiplicity of factors, the study was split into two experiments. In experiment 1 , the same $E$. amylovora strain, EPS101, was inoculated in two plant materials and cultivars (Doyenne du Comice and Conference). In experiment 2, immature pear fruit of Passe Crassane cultivar were inoculated with seven E. amylovora strains. The experimental design consisted of three repetitions of six fruit per repetition (4 wounds per fruit and a total of 24 wounds per repetition) or three repetitions of eight flowers per repetition, for each strain, plant material, and cultivar combination. The incidence of infection of individual wounds in immature pear fruit and on the hypanthium of flowers was assessed at 5 days after inoculation.

The mean proportion of infected wounds on flowers per repetition at each pathogen dose was fit to the probit and hyperbolic saturation models (31) for each strain, pear cultivar, and plant material combination. The equation of the probit model which relates incidence of infections $(y)$ to the concentration of pathogen $(x)$ is

$$
y=\phi\left[\frac{\left(\log _{10}(x)-\lambda\right)}{\tau}\right]
$$

where $\phi$ denotes the cumulative distribution function for the standard normal, $\lambda$ is a parameter equivalent to the $\mathrm{ED}_{50}$, and $\tau$ is the efficiency of the pathogen.

The equation corresponding to the hyperbolic saturation model is

$$
y=y_{\max } \frac{x}{\left(x+K_{x}\right)}
$$

where $y_{\max }$ is the maximum disease incidence and $K_{x}$ is the half saturation constant corresponding to the $\mathrm{ED}_{50}$ of the pathogen.
Regression and parameter estimation were performed by a nonlinear least squares method using the NLIN procedure of the PC-Statistical Analysis System (version 8.2; SAS Institute Inc., Cary, NC). Analysis of variance (ANOVA) was performed for each of the two experiments using the GLM procedure of the SAS. Means were separated by the Waller-Duncan test $(P \leq 0.05)$.

Kinetics of infection incidence. The aggressiveness of the 36 strains of E. amylovora described in Table 1 was evaluated on immature pear fruit using progression curves of infection incidence. The experiment was performed twice. In the first trial, the strains were inoculated at $10^{3} \mathrm{CFU} / \mathrm{ml}$ whereas, in the second experiment, inoculations were performed at $10^{5} \mathrm{CFU} / \mathrm{ml}$. The experimental design consisted of three repetitions of six fruit per repetition for each strain and concentration. Aggressiveness was evaluated on the basis of the incidence of infections that was assessed at $3,4,5,6,7,8,9$, and 10 days after the pathogen inoculation.

Infection incidence data at different times were fit to the Gompertz model (12). However, a modification of the original model was used to account for the typical delay observed in the start of infections depending on the strain. The equation of the modified Gompertz model is

$$
y=K-\exp \left(-B_{g} \cdot \exp \left[-r_{g}\left(t-t_{0}\right)\right]\right)
$$

where $K$ is the maximum disease level or curve asymptote, $r_{g}$ is the rate of disease progression, $B_{g}$ is a parameter accounting for the origin of the curve with respect to the ordinate axis, and $t_{0}$ is the time delayed to start of the disease progress curve.

Regression and parameter estimation was performed by a nonlinear least squares method using the NLIN procedure of the SAS. To improve convergence to the solution, the parameter $K$ was determined directly from curves as the incidence at the end of the incubation period and was fixed in the equation.

ANOVA was performed with the estimated parameters and means were separated by the Tukey's test at $P \leq 0.05$. The analysis was done with the GLM procedure of the SAS.

For classification of strains into different levels of aggressiveness, the following procedure was used. For each experiment and strain, a four-level index was computed. In experiment 1 , for parameter $r_{g}$, the levels of aggressiveness were: 1 , nonvirulent or very low $\left(0 \leq r_{g}<0.4\right) ; 2$, low $\left(0.4 \leq r_{g}<0.8\right) ; 3$, medium $(0.8 \leq$ $\left.r_{g}<1.2\right)$; and 4 , high $\left(1.2 \leq r_{g}<1.5\right)$. For parameter $t_{0}$, the levels of aggressiveness were: 1 , nonvirulent or very low $\left(7.5<t_{0} \leq 10\right)$; 2 , low $\left(5<t_{0} \leq 7.5\right) ; 3$, medium $\left(2.5<t_{0} \leq 5\right)$; and 4 , high $\left(0<t_{0}\right.$ $\leq 2.5$ ). For $K$ parameter, the levels of aggressiveness were: 1 , nonvirulent or very low $(0 \leq K<25)$; 2 , low $(25 \leq K<50)$; 3 , medium $(50 \leq K<75)$; and 4 , high $(K \geq 75)$. For experiment 2 , an analogous rescaling method was used. A combined index of aggressiveness also was computed for each strain as the sum of the aggressiveness levels obtained using each parameter. Finally, a four-level scale of combined index of aggressiveness (CI) was calculated as follows: 1 , nonvirulent or very low ( $3 \geq \mathrm{CI}) ; 2$, low $(3<\mathrm{CI} \leq 6) ; 3$, medium $(6<\mathrm{CI} \leq 9)$; and 4 , high $(9<\mathrm{CI} \leq 12)$. The Kuskall-Wallis rank order test was used to compare the classification of strains according to the single parameter index and the combined index of aggressiveness in the two experiments performed.

\section{RESULTS}

Infectivity titration assays. Several patterns of the effect of pathogen concentration on infection incidence at 5 days in immature pear fruit and flowers in a set of strains in different plant materials are shown in Figure 1.

The aggressiveness of strains in different plant materials according to $\lambda\left(\mathrm{ED}_{50}\right)$ and $\tau$ for the probit model, and $K_{x}\left(\mathrm{ED}_{50}\right)$ and $y_{\max }$ for the hyperbolic saturation model, is shown in Table 2. Both models adequately fit the data sets for 9 of 11 strain-plant 
material combinations studied, on the basis of the mean square error (MSE) and the asymptotic standard errors for the estimated parameters.

The values of $\mathrm{ED}_{50}$ estimated by both models were similar, ranging from $2.78 \times 10^{\mathrm{e}}$ to $7.08 \times 10^{5} \mathrm{CFU} / \mathrm{ml}$ for the hyperbolic saturation model and from 2.59 to $6.12 \log _{10} \mathrm{CFU} / \mathrm{ml}$ for the probit model. In the less aggressive strains EPS100 and NCPPB311, it was impossible to fit data to models because only the highest concentrations of pathogen gave some infected fruit.

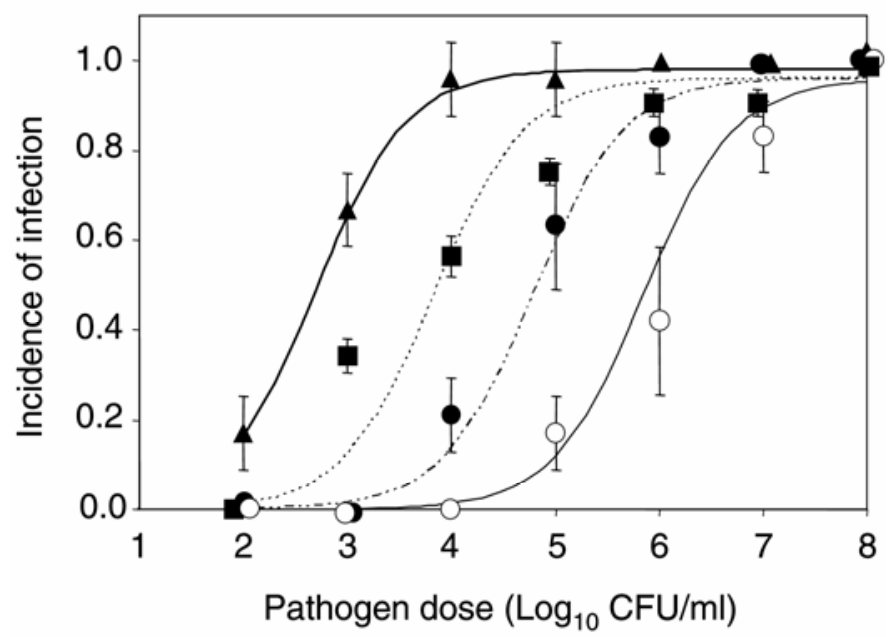

Fig. 1. Infectivity titration of strains of Erwinia amylovora in immature pear fruit of cv. Passe Crassane (EPS101, •; UPN529, - ; and NCCPB595, O) and flowers of cv. Conference (EPS101, $\mathbf{A})$. Curves represent predictions according to the hyperbolic saturation model (equation 2) using the estimated parameters shown in Table 2 . Lines indicate the confidence interval for the mean.
However, a rough estimation of $\mathrm{ED}_{50}$ was $\approx 10^{7} \mathrm{CFU} / \mathrm{ml}$ for EPS 100 and $>10^{8} \mathrm{CFU} / \mathrm{ml}$ for NCPPB311.

In experiment 1, plant material (flower and immature pear fruit) and cultivar type (Doyenne du Comice and Conference) significantly affected aggressiveness $\left(\mathrm{ED}_{50}\right)$ of strain EPS101 $(F=128.8$ and $8.7, P<0.001$ and 0.001 , respectively, using the probit model; and $F=70.7$ and $12.1, P<0.001$ and 0.001 , respectively, using the hyperbolic saturation model). In experiment 2 , the effect of the strain of E. amylovora on aggressiveness was significant ( $F=10.6, P<0.001$ for the probit model and $F=8.0, P<0.001$ for the hyperbolic saturation model). Flowers were more susceptible to E. amylovora infections (low $\mathrm{ED}_{50}$ ) than immature pear fruit (high $\mathrm{ED}_{50}$ ). $\mathrm{Cv}$. Doyenne du Comice was the more susceptible among cultivars tested. Strains EPS101, UPN611, and UPN529 were more aggressive (exhibited similar and low ED 50 ) according to both models than strain IVIA1614.2, which was intermediate (different between models), and NCPPB595 was less aggressive.

Kinetics of progression of infection incidence. The progression of disease incidence in wounded immature pear fruit inoculated with different strains of E. amylovora is shown in Figure 2. The four strains shown represent different patterns of progression of infection incidence from low (UPN610) and medium (IVIA1614.2 and NCPPB1819) to high rate of progression (EPS101), and for the time of start of the progress curve.

The aggressiveness of the 36 strains of E. amylovora listed in Table 1 was studied in relation to the progression of the incidence of infected wounds in immature Passe Crassane pear fruit (Table 3). Aggressiveness was measured according to the estimated parameters $\left(r_{g}, t_{0}\right.$, and $\left.K\right)$ obtained by fitting infection incidence progression data to the modified Gompertz model. Two experiments were performed at different doses of pathogen. Significant differences were observed among strains at $10^{3} \mathrm{CFU} / \mathrm{ml}$ (experiment 1$)$ in $r_{g}(F=44.4, P<0.001), t_{0}(F=334.5, P<0.001)$, and $K(F=114.5, P<0.001)$, and at $10^{5} \mathrm{CFU} / \mathrm{ml}$ (experiment 2$)$ in $r_{g}$

TABLE 2. Infectivity titration of strains of Erwinia amylovora in different ex vivo plant material and estimated parameters of the probit and hyperbolic saturation models that relate the incidence of infections with the pathogen concentrations ${ }^{\mathrm{z}}$

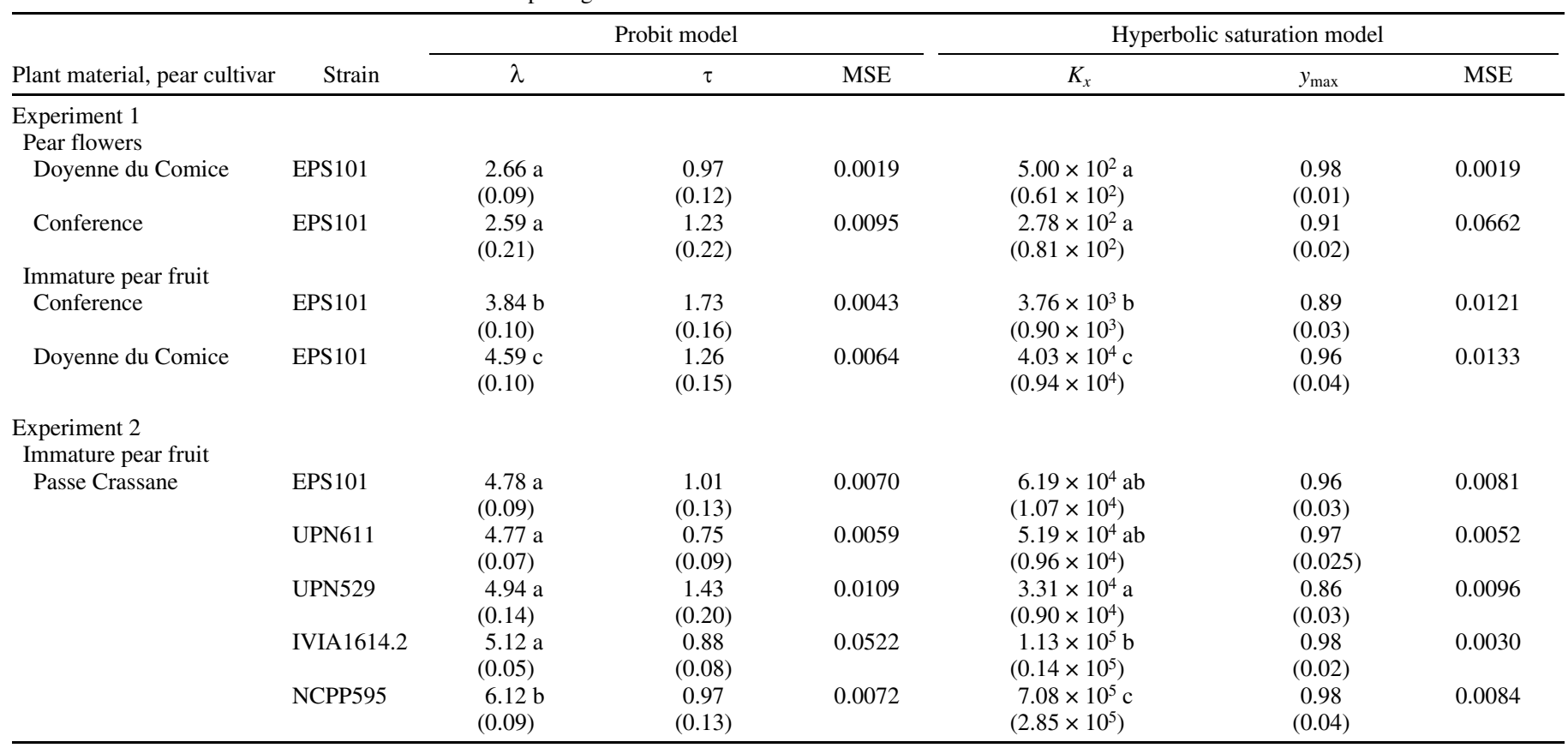

\footnotetext{
${ }^{\mathrm{z}}$ Median effective dose of the pathogen $(\mathrm{CFU} / \mathrm{ml})=\mathrm{ED}_{50}$. Model parameters according to equations 1 and 2 are $\lambda\left(\log _{10} \mathrm{ED}_{50}\right), \tau$ (efficiency of the pathogen), $K_{x}$ $\left(\mathrm{ED}_{50}\right)$, and $y_{\max }$ (maximum disease proportion). Models were fit to pooled data consisting of three repetitions of seven pathogen concentrations (21 data points). Values shown are estimated parameters for the pooled data. The asymptotic standard errors for the parameter estimates are given in parentheses. MSE $=$ mean square error of the model. Statistical comparisons were performed using model parameters estimated separately for each of the three repetitions corresponding to combinations of plant material, pear cultivar and pathogen strain. Values within the same column followed by different letters are significantly different $(P \leq$ $0.05)$ according to the Waller-Duncan test.
} 
$(F=21.2, P<0.001), t_{\mathrm{g}}(F=105.9, P<0.001)$, and $K(F=27.3$, $P<0.001)$.

At the lower pathogen dose (experiment 1), a higher variability of the parameters was observed than at the higher dose (experi-

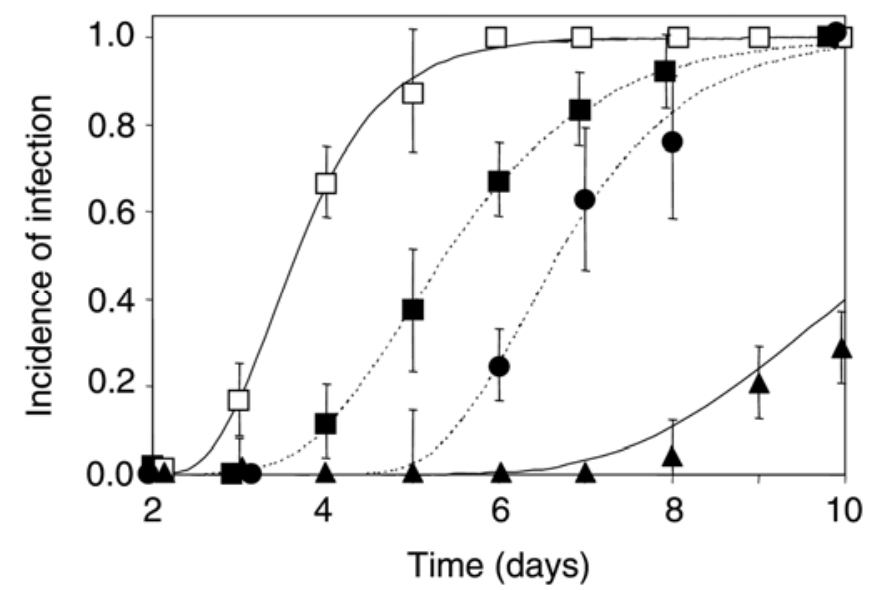

Fig. 2. Kinetics of disease progression in immature pear fruit of cv. Passe Crassane upon inoculation with strains EPS101 ( $\square)$, IVIA1614.2 (ם), NCPPB1819 (•), and UPN610 ( $\mathbf{\Delta})$ of Erwinia amylovora. Inoculations were performed at $10^{5} \mathrm{CFU} / \mathrm{ml}$. Curves represent predictions of the modified Gompertz model (equation 3) according to the parameters shown in experiment 2 in Table 3. Lines indicate the confidence interval for the mean. ment 2), and probably was due to the low inoculum concentration used. Globally, $t_{0}$ was shorter and $r_{g}$ was higher in the second experiment, whereas the values of $K$ were similar. Also, some strains showed considerable differences in $r_{g}$ values between experiments (e.g., EPS101, NCPPB595, and SIA7), whereas others (e.g., UPN611, IVIA1614.2, and Ea273) have similar values in both experiments.

Values of $r_{g}$ varied from 0 to 1.59 at the lower pathogen dose and from 0 to 1.90 at the higher dose. In both experiments, $r_{g}$ was distributed gradually and overlapped in many strains, but was clearly separated for the more and less aggressive strains. Generally, the more aggressive strains had high $r_{g}$ values and short $t_{0}$, whereas the less aggressive strains showed low $r_{g}$ and $K$ values and large $t_{0}$.

A classification of the aggressiveness of the strains was performed using the single-parameter index $\left(r_{g}, t_{0}\right.$, or $\left.K\right)$ and the combined index as described previously. According to the KruskalWallis rank order test, there were no significant differences in the classification of the strains between experiments 1 and 2 for $r_{0}$ $\left(\chi^{2}=1.07, P=0.30\right)$ and $K\left(\chi^{2}=1.41, P=0.24\right)$. However, there were differences between both experiments for $t_{0}\left(\chi^{2}=9.78, P=\right.$ 0.002). Upon using the combined index, there were no significant differences in the classification of strains between experiments according to the Kruskal-Wallis test $\left(\chi^{2}=0.95, P=0.33\right)$.

The results of the global classification obtained are presented in the last column of Table 3. The reference strains from other sources, such as CFBP1430, NCPPB3159, CUCM273, and

TABLE 3. Aggressiveness of strains of Erwinia amylovora in immature Passe Crassane pear fruit according to the kinetics of disease progression ${ }^{\mathrm{y}}$

\begin{tabular}{|c|c|c|c|c|c|c|c|}
\hline \multirow[b]{2}{*}{ Strain } & \multicolumn{3}{|c|}{ Experiment 1} & \multicolumn{3}{|c|}{ Experiment 2} & \multirow[b]{2}{*}{ Combined class ${ }^{\mathrm{Z}}$} \\
\hline & $r_{g}$ & $t_{0}$ & $K$ & $r_{g}$ & $t_{0}$ & $K$ & \\
\hline SV4408 & $1.49 \mathrm{a}-\mathrm{c}$ & $4.07 \mathrm{e}-\mathrm{h}$ & $100 \mathrm{a}$ & $1.90 \mathrm{a}$ & $2.04 \mathrm{~h}-\mathrm{m}$ & $100 \mathrm{a}$ & $4 / 4$ \\
\hline SV2773 & $1.42 \mathrm{a}-\mathrm{d}$ & $4.35 \mathrm{de}$ & $100 \mathrm{a}$ & $1.70 \mathrm{a}-\mathrm{b}$ & $2.86 \mathrm{~h}-\mathrm{k}$ & $100 \mathrm{a}$ & $4 / 4$ \\
\hline SV4300 & $1.46 \mathrm{a}-\mathrm{c}$ & $4.00 \mathrm{e}-\mathrm{i}$ & $100 \mathrm{a}$ & $1.61 \mathrm{a}-\mathrm{c}$ & $3.06 \mathrm{~g}-\mathrm{i}$ & $100 \mathrm{a}$ & $4 / 4$ \\
\hline UPN500 & $1.52 \mathrm{ab}$ & $4.31 \mathrm{~d}-\mathrm{f}$ & $100 \mathrm{a}$ & $1.56 \mathrm{a}-\mathrm{d}$ & $2.87 \mathrm{~h}-\mathrm{k}$ & $100 \mathrm{a}$ & $4 / 4$ \\
\hline UPN513 & $1.36 \mathrm{a}-\mathrm{e}$ & $3.19 \mathrm{~g}-1$ & $100 \mathrm{a}$ & $1.56 \mathrm{a}-\mathrm{d}$ & $1.58 \mathrm{~lm}$ & $100 \mathrm{a}$ & $4 / 4$ \\
\hline SV4320 & $1.59 \mathrm{a}$ & $4.21 \mathrm{~d}-\mathrm{g}$ & $100 \mathrm{a}$ & $1.54 \mathrm{a}-\mathrm{d}$ & $3.07 \mathrm{~g}-\mathrm{i}$ & $100 \mathrm{a}$ & $4 / 4$ \\
\hline SV4499 & $1.16 \mathrm{a}-\mathrm{g}$ & $3.41 \mathrm{e}-1$ & $100 \mathrm{a}$ & $1.41 \mathrm{a}-\mathrm{e}$ & $2.84 \mathrm{~h}-\mathrm{k}$ & $100 \mathrm{a}$ & $4 / 4$ \\
\hline SV4576 & $1.51 \mathrm{ab}$ & $2.92 \mathrm{i}-1$ & $100 \mathrm{a}$ & $1.49 \mathrm{a}-\mathrm{d}$ & $1.74 \mathrm{k}-\mathrm{m}$ & $100 \mathrm{a}$ & $4 / 4$ \\
\hline UPN530 & $0.99 \mathrm{c}-\mathrm{h}$ & $4.11 \mathrm{e}-\mathrm{h}$ & $100 \mathrm{a}$ & $1.57 \mathrm{a}-\mathrm{d}$ & $2.97 \mathrm{~h}-\mathrm{j}$ & $100 \mathrm{a}$ & $4 / 4$ \\
\hline EPS101 & $0.84 \mathrm{f}-\mathrm{h}$ & $3.51 \mathrm{e}-\mathrm{k}$ & $96 \mathrm{a}$ & $1.46 \mathrm{a}-\mathrm{d}$ & $1.86 \mathrm{j}-\mathrm{m}$ & $100 \mathrm{a}$ & $4 / 4$ \\
\hline CFBP1430 & $1.05 \mathrm{~b}-\mathrm{h}$ & $2.61 \mathrm{j}-1$ & $100 \mathrm{a}$ & $1.44 \mathrm{a}-\mathrm{e}$ & $1.29 \mathrm{~m}$ & $100 \mathrm{a}$ & $4 / 4$ \\
\hline UPN514 & $1.15 \mathrm{a}-\mathrm{g}$ & 2.381 & $100 \mathrm{a}$ & $1.35 \mathrm{~b}-\mathrm{f}$ & $2.21 \mathrm{~h}-\mathrm{m}$ & $100 \mathrm{a}$ & $4 / 4$ \\
\hline NCPPB3159 & $1.11 \mathrm{a}-\mathrm{g}$ & $4.39 \mathrm{de}$ & $100 \mathrm{a}$ & $1.31 \mathrm{~b}-\mathrm{g}$ & $3.21 \mathrm{f}-\mathrm{h}$ & $100 \mathrm{a}$ & $4 / 4$ \\
\hline UPN611 & $1.25 \mathrm{a}-\mathrm{f}$ & $3.17 \mathrm{~g}-1$ & $100 \mathrm{a}$ & $1.23 \mathrm{~b}-\mathrm{h}$ & $2.06 \mathrm{~h}-\mathrm{m}$ & $100 \mathrm{a}$ & $4 / 4$ \\
\hline $\mathrm{Ea} 273$ & $1.09 \mathrm{a}-\mathrm{g}$ & $4.10 \mathrm{e}-\mathrm{h}$ & $92 \mathrm{a}$ & $1.13 \mathrm{c}-\mathrm{h}$ & $1.96 \mathrm{i}-\mathrm{m}$ & $100 \mathrm{a}$ & $4 / 4$ \\
\hline SIA1 & $0.83 \mathrm{f}-\mathrm{h}$ & $4.51 \mathrm{de}$ & $100 \mathrm{a}$ & $1.13 \mathrm{c}-\mathrm{h}$ & $1.73 \mathrm{k}-\mathrm{m}$ & $100 \mathrm{a}$ & $4 / 4$ \\
\hline IVIA1614.2 & $0.91 \mathrm{e}-\mathrm{h}$ & 3.04 h-1 & $100 \mathrm{a}$ & $1.03 \mathrm{~d}-\mathrm{h}$ & $1.99 \mathrm{i}-\mathrm{m}$ & $100 \mathrm{a}$ & $4 / 4$ \\
\hline NCPPB1734 & $0.95 \mathrm{~d}-\mathrm{h}$ & $4.19 \mathrm{~d}-\mathrm{g}$ & $88 \mathrm{ab}$ & $0.85 \mathrm{f}-\mathrm{i}$ & $2.37 \mathrm{~h}-\mathrm{m}$ & $88 \mathrm{a}-\mathrm{c}$ & $4 / 4$ \\
\hline SV4500 & $0.74 \mathrm{gh}$ & $4.38 \mathrm{de}$ & $67 \mathrm{bc}$ & $1.13 \mathrm{c}-\mathrm{h}$ & $2.13 \mathrm{~h}-\mathrm{m}$ & $100 \mathrm{a}$ & $3 / 4$ \\
\hline NCPPB2080 & $0.85 \mathrm{e}-\mathrm{h}$ & $5.29 \mathrm{~cd}$ & $67 \mathrm{bc}$ & $1.12 \mathrm{c}-\mathrm{h}$ & $3.03 \mathrm{~g}-\mathrm{j}$ & $100 \mathrm{a}$ & $3 / 4$ \\
\hline SV1000 & $0.55 \mathrm{hi}$ & $3.23 \mathrm{f}-1$ & $92 \mathrm{a}$ & $1.12 \mathrm{c}-\mathrm{h}$ & $2.73 \mathrm{~h}-1$ & $100 \mathrm{a}$ & $3 / 4$ \\
\hline NCPPB683 & $0.86 \mathrm{e}-\mathrm{h}$ & $3.67 \mathrm{e}-\mathrm{j}$ & $100 \mathrm{a}$ & $0.88 \mathrm{e}-\mathrm{i}$ & $3.14 \mathrm{~g}-\mathrm{i}$ & $100 \mathrm{a}$ & $4 / 3$ \\
\hline UPN529 & $0.71 \mathrm{~g}-\mathrm{h}$ & $4.35 \mathrm{de}$ & $21 \mathrm{~d}$ & $1.51 \mathrm{a}-\mathrm{d}$ & $2.69 \mathrm{~h}-1$ & $100 \mathrm{a}$ & $2 / 4$ \\
\hline NCPPB1819 & $0.81 \mathrm{f}-\mathrm{h}$ & $5.81 \mathrm{c}$ & $59 c$ & $0.81 \mathrm{f}-\mathrm{i}$ & 4.40 ef & $67 \mathrm{de}$ & $3 / 3$ \\
\hline SIA7 & $0.00 \mathrm{j}$ & $>10.00 \mathrm{a}$ & $0 \mathrm{~d}$ & $0.81 \mathrm{f}-\mathrm{i}$ & $4.17 \mathrm{e}-\mathrm{g}$ & 58 ef & $1 / 3$ \\
\hline SIA13 & $0.00 \mathrm{j}$ & $>10.00 \mathrm{a}$ & $17 \mathrm{~d}$ & $0.76 \mathrm{~g}-\mathrm{j}$ & $4.72 \mathrm{de}$ & $71 \mathrm{de}$ & $1 / 3$ \\
\hline 115.22 & $0.00 \mathrm{j}$ & $>10.00 \mathrm{a}$ & $13 \mathrm{~d}$ & $0.69 \mathrm{~h}-\mathrm{j}$ & $2.29 \mathrm{~h}-\mathrm{m}$ & $79 b-d$ & $1 / 3$ \\
\hline NCPPB595 & $0.57 \mathrm{hi}$ & $7.95 \mathrm{~b}$ & $5 \mathrm{~d}$ & $1.05 \mathrm{c}-\mathrm{h}$ & $6.01 \mathrm{c}$ & $46 \mathrm{fg}$ & $1 / 2$ \\
\hline UPN575 & $0.00 \mathrm{j}$ & $>10.00 \mathrm{a}$ & $0 \mathrm{~d}$ & $0.81 \mathrm{f}-\mathrm{i}$ & $4.69 \mathrm{de}$ & $33 \mathrm{~g}$ & $1 / 2$ \\
\hline EPS100 & $0.18 \mathrm{ij}$ & $6.00 \mathrm{c}$ & $21 \mathrm{~d}$ & $0.24 \mathrm{jk}$ & $5.62 \mathrm{~cd}$ & $29 \mathrm{~g}$ & $1 / 1$ \\
\hline UPN609 & $0.00 \mathrm{j}$ & $>10.00 \mathrm{a}$ & $0 \mathrm{~d}$ & $0.42 \mathrm{i}-\mathrm{k}$ & $7.25 \mathrm{~b}$ & $4 \mathrm{~h}$ & $1 / 1$ \\
\hline UPN610 & $0.00 \mathrm{j}$ & $>10.00 \mathrm{a}$ & $0 \mathrm{~d}$ & $0.40 \mathrm{i}-\mathrm{k}$ & $7.43 \mathrm{~b}$ & $4 \mathrm{~h}$ & $1 / 1$ \\
\hline UPN562 & $0.00 \mathrm{j}$ & $>10.00 \mathrm{a}$ & $0 \mathrm{~d}$ & $0.39 \mathrm{i}-\mathrm{k}$ & $7.64 \mathrm{~b}$ & $29 \mathrm{~g}$ & $1 / 1$ \\
\hline UPN546 & $0.00 \mathrm{j}$ & $>10.00 \mathrm{a}$ & $0 \mathrm{~d}$ & $0.38 \mathrm{i}-\mathrm{k}$ & $7.61 \mathrm{~b}$ & $4 \mathrm{~h}$ & $1 / 1$ \\
\hline NCPPB311 & $0.00 \mathrm{j}$ & $>10.00 \mathrm{a}$ & $0 \mathrm{~d}$ & $0.00 \mathrm{k}$ & $>10.00 \mathrm{a}$ & $0 \mathrm{~h}$ & $1 / 1$ \\
\hline PMV6076 & $0.00 \mathrm{j}$ & $>10.00 \mathrm{a}$ & $0 \mathrm{~d}$ & $0.00 \mathrm{k}$ & $>10.00 \mathrm{a}$ & $0 \mathrm{~h}$ & $1 / 1$ \\
\hline
\end{tabular}

y Parameters $r_{g}, t_{0}$, and $K$ were obtained by fitting disease incidence progression data to the modified Gompertz model given in equation 3. Results for the two experiments performed are shown. Means within the same column followed by different letters are significantly different $(P \leq 0.05)$ according to Tukey's test. Experiments 1 and 2 were performed at an initial pathogen concentration of $10^{3}$ and $10^{5} \mathrm{CFU} / \mathrm{ml}$, respectively.

${ }^{\mathrm{z}}$ Obtained upon rescaling each parameter from 1 to 4 and calculating a global index $r_{g}+t_{0}+K$. First and second numbers correspond to experiments 1 and 2 , respectively. 
NCPPB1734, showed high aggressiveness. Strains NCPPB2080, NCPPB683, NCPPB1819, and NCPPB595 showed moderate aggressiveness and strain 115.22 showed low aggressiveness. Strain NCPPB311 and the mutant PMV6076 were nonvirulent. The Spanish strains were distributed in the four classes of aggressiveness, but were more frequent in the highly aggressive group $(56 \%)$.

Relationships between $\boldsymbol{r}_{g}, \mathbf{E D}_{\mathbf{5 0}}$, and $\boldsymbol{t}_{\mathbf{0}}$. Only 11 data points were included in these analyses, resulting from the combinations of strain, plant material, and cultivar that were analyzed with both infectivity titration and kinetics of progression of infection incidence. An inverse relationship was observed between $r_{g}$ and $\mathrm{ED}_{50}$, and a direct relationship was observed between $t_{0}$ and $\mathrm{ED}_{50}$ (Fig. $3)$. Also, a multiple linear regression analysis indicated a relationship between the three parameters $\left(\mathrm{ED}_{50}=6.31+0.174 t_{0}-2.49 r_{g}\right.$; $\left.R^{2}=0.84\right)$. Therefore, a clear partitioning of the aggressiveness into infectiveness and invasiveness was not possible because of the correlation between the three parameters.

\section{DISCUSSION}

This study found differences in aggressiveness among an extensive collection of strains of E. amylovora composed of isolates from Spanish outbreaks of fire blight and reference strains from different geographical origins. This was, in part, because of the wide range of origin of the strains, dose of pathogen, plant material type, time of incubation, and accurate control of environmental conditions during the assays.

Modeling data sets was necessary to summarize differences in aggressiveness among strains because the dose of pathogen and time of incubation had an effect on disease levels (measurement of the proportion of infected flowers or fruit). The system consisted of a procedure of nonlinear fit to mathematical equations relating incidence of infection to dose of pathogen (probit and hyperbolic saturation models) and time of incubation upon pathogen inoculation (modified Gompertz model). The models fit well to the data, providing a tool to determine parameters related to aggressiveness such, as $\mathrm{ED}_{50}$, time delayed to start of the infection progress curve $\left(t_{0}\right)$, and rate of progression of incidence of infections $\left(r_{g}\right)$.

Values of $\mathrm{ED}_{50}$ have not been reported previously for $E$. amylovora. However, an approximate estimation for comparison purposes can be obtained from data provided in some reports. Vanneste $(54,55)$ showed that the proportion of immature pear fruit infected upon 3 days of inoculation with a strain of E. amylovora approached 1 when using pathogen concentrations ranging from $10^{4}$ to $10^{5} \mathrm{CFU} / \mathrm{ml}$, suggesting that $\mathrm{ED}_{50}$ was lower than $10^{4} \mathrm{CFU} / \mathrm{ml}$ under these experimental conditions. Other reports reflected the low susceptibility of the plant material or the low aggressiveness of the strain used. For example, we estimated values of $\mathrm{ED}_{50}$ at $\approx 10^{8} \mathrm{CFU} / \mathrm{ml}$ for apple plantlets inoculated in vitro with strain E4001A $(33,34)$ and shoots of hawthorn in the greenhouse inoculated with strain Ea519 (56). These data are in agreement with values of $\mathrm{ED}_{50}$ ranging from $10^{2}$ to $10^{8} \mathrm{CFU} / \mathrm{ml}$ observed in the present study from infectivity titration experiments.

Values of $r_{g}$, either directly reported or calculated using data from other works, are in agreement with our findings from near 0 to $1.90 \mathrm{day}^{-1}$. An $r_{g}$ of $2.22 \mathrm{day}^{-1}$ in immature pear fruit was calculated from raw data of Vanneste $(54,55)$ in accordance with our results for the most aggressive strains inoculated in the most susceptible plant material. Values of $r_{g}$ ranging from 0.10 to 0.43 day $^{-1}$ were calculated from raw data on strain E4001A inoculated to in vitro apple plants of cv. Novole $(33,34)$, and for a strain inoculated in pear seedlings of cv. Durondeau in the greenhouse (17). Also, in greenhouse trials using pear (cvs. Kirchensaller and Doyenne du Comice) and apple seedlings (cv. Golden Delicious), values of $r_{g}$ ranged from 0.14 to 0.29 day $^{-1}$ (L. Ruz and J. Cabrefiga, unpublished data). However, lower values of $r_{g}$ of
0.03 day $^{-1}$ have been reported in field trials in pear and apple shoots of six cultivars (30). Therefore, differences in $r_{g}$ between reports can be attributed to the different susceptibility of the plant material used, the environmental conditions (greenhouse or field trials), and the aggressiveness of the strain used. However, in our study, these differences in $r_{g}$ are due to strain variability because the plant material and environmental conditions were fixed.

From the infectivity titration experiments, a minimum infective dose (MID) can be calculated for each strain. A threshold value of 0.2 (mean of the confidence intervals for the disease proportion data) can be considered as significantly different from zero. Therefore, the minimum dose of pathogen causing a disease level higher than 0.2 can be considered as the MID. Accordingly, MID values from $10^{2}$ (detached flowers) to $10^{5} \mathrm{CFU} / \mathrm{ml}$ (immature fruit) can be calculated easily from data of Table 2 . Taking into account the inoculation volume used $(10 \mu \mathrm{l})$, the MID can be estimated from 1 to $1,000 \mathrm{CFU}$ per inoculation site. This means that, under highly favorable conditions, as much as one viable cell of E. amylovora is enough to develop an infection. This is of particular importance when taking into account the fact that the concentration of viable bacteria in the typical ooze produced in infected plant tissues in the field under certain conditions can account for $10^{9}$ to $10^{10} \mathrm{CFU} /$ drop (J. Cabrefiga, data not shown). Under field conditions, this inoculum can be distributed by several abiotic (thunderstorms or wind aerosols) or biotic (insects) agents, and has been considered important in disease spread $(21,53,55)$. The low MID of the pathogen and the high inoculum potential of ooze illustrates the enormous capacity for spread of fire blight. Another implication of the low MID for this pathogen concerns the methods of detection and analysis of E. amylovora. The level

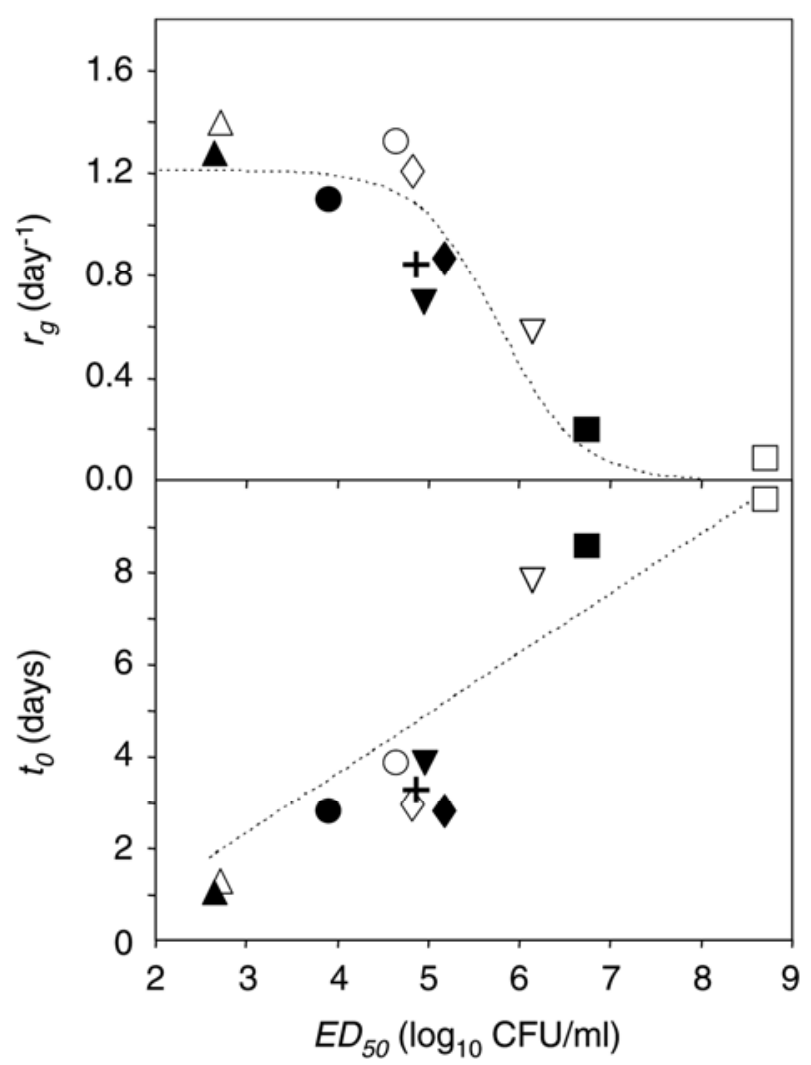

Fig. 3. Relationships between the rate of disease progression $\left(r_{g}\right)$ and time to start of the disease progression curve $\left(t_{0}\right)$ at $10^{3} \mathrm{CFU} / \mathrm{ml}$ with median effective dose $\left(\mathrm{ED}_{50}\right)$ at 5 days from inoculation for strains of Erwinia amylovora. The symbols correspond to immature pear fruit of cvs. Passe Crassane strains

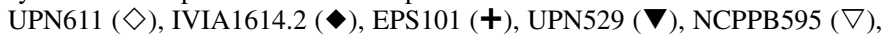

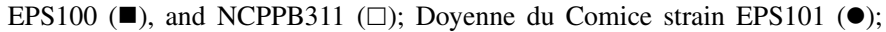
and Conference (strain EPS101 (O); and detached pear flowers of Doyenne du Comice strain EPS101 $(\boldsymbol{\Delta})$ and Conference $(\Delta)$. 
of detection typically used in assays needs to be improved, especially in propagation plant material from nurseries, in order to prevent delivery of symptomless plants harboring incipient infections or infective population levels below the assessed detection level $\left(\approx 10^{3} \mathrm{CFU} / \mathrm{g}\right.$ fresh weight or susceptible entry site).

The efficiency parameter $(\tau)$ provided by the probit model can be related to the degree of independence of action of the pathogen cells during infection. Peto (42) demonstrated mathematically that $\tau$ should be below or $\approx 2$ if pathogen cells are acting independently during infection. This hypothesis was confirmed in laboratory and field experiments with Pseudomonas syringae on several hosts $(15,42)$. Fitting the probit model to infectivity titration data of E. amylovora leads to $\tau$ values which are consistent with the hypothesis of independent action of pathogen cells on pear $(\tau$ from 0.75 to 1.73 ). Furthermore, this result suggests that the value itself may be an indication of the degree of independence.

In the two experiments performed at different pathogen doses in the study of the kinetics of incidence of infection in immature pear fruit, the effect of dose on $r_{g}$ was pronounced in some strains whereas, in others, it was not significant. This differential effect is related to $\tau$, the efficiency parameter of the probit-dose relationship, which is an indication of the degree of independence of cells during the infection process. This hypothesis is supported by the fact that there is a significant direct correlation between the percentage of increase in $r_{g}$ upon dose increase and the $\tau$ values $\left(R^{2}=\right.$ $0.784, P<0.01$ ) for the six strains shown in Table 3 . Thus, strains with low values of $\tau$ (e.g., UPN611; high degree of independency) showed smaller or no changes in $r_{g}$ upon increase of dose, whereas strains with higher values of $\tau$ (e.g., UPN529) showed significant changes.

The values of $r_{g}$ and $t_{0}$ presented in this work also provide valuable kinetic information on potential disease development in the field. In spite of the variability observed due to strain differences, mean values of $r_{g}$ of 1.2 day $^{-1}$ and of $t_{0}$ of 3.52 days can be estimated. These values agreed with the frequent observation of symptoms 3 to 4 days after risk warning by fire blight forecasting models (e.g., Maryblit), and also with the duration of fire blight epidemics from detection of first symptoms to maximal disease levels under optimal conditions. However, most fire blight prediction models actually are based on the effect of temperature according to data on in vitro cultures of E. amylovora (44). The tools provided in the present work would help in calculation of $r_{g}$ and $t_{0}$ in host plants other than pear and under different environmental conditions (e.g., temperature), and these values would be useful to improve fire blight forecasting models.

The combined index obtained using $r_{g}, t_{0}$, and $K$ was useful for classifying strains according to aggressiveness. This is the first time that several reference strains of different geographical and host origin have been tested in the same assay. However, the results of the present work for strains Ea273 and CFBP1430, classified as highly aggressive, agreed with previous reports (22,34-48).

Most of the highly aggressive strains on pear originally were isolated from pear, whereas the nonvirulent or less aggressive

TABLE 4. Suggested scale for the classification of strains of Erwinia amylovora according to the parameters obtained from infectivity titration and kinetics of infection incidence progression in the immature Passe Crassane pear fruit test

\begin{tabular}{llll}
\hline & \multicolumn{3}{c}{ Classification of aggressiveness } \\
\cline { 2 - 4 } Parameter $^{\mathrm{z}}$ & High & Medium & Low \\
\hline $\log \left(\mathrm{ED}_{50}\right)(\mathrm{CFU} / \mathrm{ml})$ & $<5$ & $5-6$ & $>6$ \\
$t_{0}($ day $)$ & $<3$ & $3-6$ & $>6$ \\
$r_{g}\left(\right.$ day $\left.^{-1}\right)$ & $>1.2$ & $0.6-1.2$ & $<0.6$ \\
\hline
\end{tabular}

${ }^{\mathrm{z}}$ Median effective dose of the pathogen $(\mathrm{CFU} / \mathrm{ml})=\mathrm{ED}_{50}$, rate of infection incidence progression $=r_{g}$, and time delayed to start of the incidence progress curve $=t_{0}$. strains were isolated from different hosts. This observation supports the hypothesis of a certain degree of host specificity among pear isolates based on analysis of aggressiveness, in accordance with a certain host species-specificity described for some strains by other authors $(2,33)$. However, it contrasts with the very low variability at genetic and phenotypic level observed in this pathogen $(19,22,28,29,41)$. Carbon source utilization profiles (22) and repetitive DNA and ribotyping PCR (26), random amplified polymorphic DNA fragment analysis (28), and amplified 16S-23S ribosomal DNA restriction enzyme analysis (29) have enabled the ability to distinguish strains isolated from fruit trees (Maloideae) from strains isolated from Rubus spp. Studies using molecular techniques capable of detecting high genetic variability, such as inverse sequence-tagged repeat (40) or amplified fragment length polymorphism analysis (41), have revealed polymorphisms among Spanish isolates of E. amylovora, though the resulting clusters were not correlated with host, year, or country of isolation. However, a more thorough study should be performed using the tools provided here to analyze aggressiveness in combination with genetic analysis to confirm this hypothesis.

A clear-cut partitioning of aggressiveness into infectiveness and invasiveness based on $\mathrm{ED}_{50}, t_{0}$, and $r_{g}$ cannot be done because of the significant correlation observed between these parameters. However, the information obtained by the combination of $\mathrm{ED}_{50}$, $r_{g}$, and $t_{0}$, can be used as a more complete quantitative tool for measurement of aggressiveness of a given strain. A standardized scale on a basis of three levels is proposed, consisting of highly aggressive (low $\mathrm{ED}_{50}$, short $t_{0}$, and high $r_{g}$ ), moderately aggressive (medium $\mathrm{ED}_{50}, t_{0}$, and $r_{g}$ ), and low aggressive (high $\mathrm{ED}_{50}$, long $t_{0}$, and low $r_{g}$ ). Because the parameters are correlated, any of them can be used. Therefore, the immature pear test, for its simplicity, is proposed as a standardized test under the conditions of assay described in the present work. The range of values for each parameter in relation to aggressiveness is indicated in Table 4. These ranges have been calculated on the basis of the results of $\mathrm{ED}_{50}$ for the five strains tested in Passe Crassane fruit (Table 2) and $r_{g}$ and $t_{0}$ at the high dose of inoculation (Table 3 ). In cases where different plant material or cultivars are used, the scale can be adjusted simply by including highly aggressive (e.g., EPS101) and very low-aggressive (e.g., NCPPB595) strains as controls.

The wide range of aggressiveness between strains observed using the methods described here, and the fact that results were affected by plant material type and cultivar, are in agreement with several studies using different methods. Previous reports have described variability in susceptibility to fire blight among hosts, cultivars, and plant material type $(8,14,23,35,36,50)$ and in aggressiveness (named as virulence) among strains of E. amylovora $(17,25,34)$. Others have studied the interaction between host and pathogen on aggressiveness (33). However, none of them used quantitative methods accounting for the effect of dose and time in terms of $\mathrm{ED}_{50}, t_{0}$, and $r_{g}$.

Finally, the methods proposed and tested in the present study were proven useful to describe aggressiveness in E. amylovora, but it is expected they also would be fruitful in studies involving other pathosystems.

\section{ACKNOWLEDGMENTS}

This research was supported by grants AGF98-0402, AGL2001-2349, and AGL2003-03354 from the Comisión Interministerial de Ciencia y Tecnología (CICYT) of Spain and 2001SGR00293 from CIRIT-Generalitat de Catalunya. We thank J. Pereda and O. Montojo for skillful assistance.

\section{LITERATURE CITED}

1. Andrivon, D. 1993. Nomenclature for pathogenicity and virulence: The need for precision. Phytopathology 83:889-890.

2. Beer, S. V., Kim, J. H., Gustafson, H. L., Zumoff, C. H., Momol, M. T., Bogdanove, A. J., Lady, R. J., Tanii, A., Tamura, O., and Aldwinckle, H. 
S. 1996. Characterization of bacteria that cause bacterial shoot blight of pear in Japan. Acta Hortic. 411:79-181.

3. Beer, S. V., and Rundle, J. R. 1983. Suppression of Erwinia amylovora by Erwinia herbicola in immature pear fruits (Abstr.). Phytopathology 73:1346.

4. Bereswill, S., Bugert, P., Bruchmüller, I., and Geider, K. 1995. Identification of Erwinia amylovora by PCR with chromosomal DNA. Appl. Environ. Microbiol. 61:2636-2642.

5. Bereswill, S., Jock, S., Bellemann, P., and Geider, K. 1998. Identification of Erwinia amylovora by growth morphology on agar containing copper sulphate and by capsule staining with lectin. Plant Dis. 82:158-164.

6. Bereswill, S., Pahl, A., Bellemann, P., Zeller, W., and Geider, K. 1992. Sensitive and species specific detection of Erwinia amylovora by PCRanalysis. Appl. Environ. Microbiol. 58:3522-3526.

7. Billing, E., Baker, L. A. E., Crosse, J. E., and Garret, C. M. E. 1961. Characteristics of English isolates of Erwinia amylovora (Burril) Winslow et al. J. Appl. Bacteriol. 24:195-211.

8. Bogs, J., Richter, K., Kim, W.-S., Jock, S., and Geider, K. 2004. Alternative methods to describe aggressiveness of Erwinia amylovora and host-plant resistance against fireblight. Plant Pathol. 53:80-89.

9. Bos, L. 1983. Introduction to Plant Virology. Longman, PUDOC/London/ New York.

10. Bos, L., and Parlevliet, J. E. 1995. Concepts and terminology on plant/pest relationships: Towards consensus in plant pathology and crop protection. Annu. Rev. Phytopathol. 33:69-102.

11. Calzolari, A., Finelli, F., and Mazzoli, G. L. 1999. A severe unforeseen outbreak of fire blight in the Emilia-Romagna region. Acta Hortic. 489:171-176

12. Campbell, C. L., and Madden, L. V. 1990. Introduction to Plant Disease Epidemiology. Wiley-Interscience, New York.

13. Casadevall, A., and Pirofski, L. 2001. Host-pathogen interactions: The attributes of virulence. J. Infect. Dis. 184:337-344.

14. Duron, M., Paulin, J. P., and Brisset, M. N. 1987. Use of in vitro propagated plant material for rating fire blight susceptibility. Acta Hortic. 217:317-324

15. Ercolani, G. L. 1973. Two hypotheses on the aetiology of response of plants to phytopathogenic bacteria. J. Gen. Microbiol. 74:83-95.

16. Fukui, R., Campbell, G. S., and Cook, R. J. 1994. Factors influencing the incidence of embryo infection by Pythium spp. during germination of wheat seeds in soils. Phytopathology 84:695-702.

17. Goodman, R. N. 1973. Variation in Erwinia amylovora with respect to virulence. (Abstr.) 2nd Int. Congr. Plant Pathol.

18. Gorris, M. T., Cambra, M., Lecomte, P., Llop, P., Charlier, R., Paulin, J. P., and López, M. M. 1996. A sensitive and specific detection of Erwinia amylovora based on ELISA-DASI enrichment method with monoclonal antibodies. Acta Hortic. 411:41-46.

19. Jock, S., Donat, V., Lopez, M. M., Bazzi, C., and Geider, K. 2002. Following spread of fire blight in Western, Central and Southern Europe by molecular differentiation of Erwinia amylovora strains with PFGE analysis. Environ. Microbiol. 4:106-114.

20. Johnson, K. B. 1994. Dose-response relationships and inundative biological control. Phytopathology 84:780-784

21. Johnson, K. B., Stockwell, V. O., McLaughlin, R. J., Sugar, D., Loper, J. E., and Roberts, R. G. 1993. Effect of antagonistic bacteria on the establishment of honey bee-dispersed Erwinia amylovora in pear blossoms and on fire blight control. Phytopathology 83:995-1002.

22. Kim, J. H., Beer, S. V., Zumoff, C. H., Laby, R. J., Gustafson, H. L., Aldwinckle, H. S., and Tanii, A. 1996. Characterization of Erwinia amylovora strains from different hosts and geographical areas. Acta Hortic. 411:183-186

23. Le Lézec, M., Lecomte, P., Laurens, F., and Michelesi, J. 1997. Sensibilité variétale au feu bacterien. Arboric. Fruit. 503:57-61; 504:33-37; 505:31-40.

24. López, M. M., Gorris, M. T., Llop, P., Cambra, M., Borruel, M., Plaza, B., Roselló, M., García, P., Palomo, J. L., and Berra, D. 1999. Fire blight in Spain: Situation and monitoring. Acta Hortic. 489:187-192.

25. Manulis, S., Kleitman, F., Dror, O., David, I., and Zutra, D. 1998. Characterization of the Erwinia amylovora population in Israel. Phytoparasitica 26:39-46

26. McManus, P. S., and Jones, A. L. 1995. Genetic fingerprinting of Erwinia amylovora strains isolated from tree-fruit crops and Rubus spp. Phytopathology 85:1547-1553.

27. Miller, T. D., and Schroth, M. N. 1972. Monitoring the epiphytic population of Erwinia amylovora on pear with a selective medium. Phytopathology 62:1175-1182.

28. Momol, M. T., Momol, E. A., Lamboy, W. F., Norelli, J. L., Beer, S. V., and Aldwinckle, H. S. 1997. Characterization of Erwinia amylovora strains using random amplified polymorphic DNA fragments (RAPDs). J. Appl. Microbiol. 82:389-398.
29. Momol, M. T., Momol, E. A., Norelli, J. L., Beer, S. V., Burr, T. J., and Aldwinckle, H. S. 1999. Relatedness of Erwinia amylovora strains based on amplified 16S-23S ribosomal DNA restriction enzyme analysisARDREA. Acta Hortic. 489:55-59.

30. Momol, M. T., and Zeller, W. 1993. Comparison of disease progression of fire blight on apple and pear cultivars. Acta Hortic. 338:123-129.

31. Montesinos, E., and Bonaterra, A. 1996. Dose-response models in biological control of plant pathogens: An empirical verification. Phytopathology 86:464-472.

32. Montesinos, E., and Vilardell, P. 1991. Relationships among population levels of Pseudomonas syringae, amount of ice nuclei, and incidence of blast of dormant flower buds in commercial pear orchards in Calalunya, Spain. Phytopathology 81:113-119.

33. Norelli, J. L., Aldwinckle, H. S., and Beer, S. V. 1984. Differential hostpathogen interactions among cultivars of apple and strains of Erwinia amylovora. Phytopathology 74:136-139.

34. Norelli, J. L., Aldwinckle, H. S., and Beer, S. V. 1988. Virulence of Erwinia amylovora strains to Malus sp. Novole plants grown in vitro and in the greenhouse. Phytopathology 78:1292-1297.

35. Paulin, J. P., Lachaud, G., and Lespinasse, Y. 1993. Role of the aggressiveness of strains of Erwinia amylovora in the experimental evaluation of susceptibility of apple cultivars to fire blight. Acta Hortic. 338:375-376.

36. Paulin, J. P., and Lespinasse, Y. 1990. Pathogenicity of strains of Erwinia amylovora to some apple cultivars in the greenhouse. Acta Hortic. 273:319-326.

37. Pusey, P. L. 1997. Crab apple blossoms as a model for research on biological control of fire blight. Phytopathology 87:1096-1102.

38. Pusey, P. L. 2002. Biological control agents for fire blight of apple compared under conditions limiting natural dispersal. Plant Dis. 86:639-644.

39. Quamme, H. A., and Bonn, W. G. 1981. Virulence of Erwinia amylovora and its influence on the determination of fire blight resistance of pear cultivars and seedlings. Can. J. Plant Pathol. 3:187-282.

40. Rico, A. 2003. Genotypic and phenotypic characterisation of the phytopathogenic bacteria Erwinia amylovora and Pseudomonas syringae. Ph.D. thesis. Universidad Pública de Navarra.

41. Rico, A., Ortiz-Barredo, A., Ritter, E., and Murillo, J. 2004. Genetic characterization of Erwinia amylovora strains by amplified fragment length polymorphism. J. Appl. Microbiol. 96:302-310.

42. Rouse, D. I., Nordheim, E. V., Hirano, S. S., and Upper, C. D. 1985. A model relating the probability of foliar disease incidence to the population frequencies of bacterial plant pathogens. Phytopathology 75:505-509.

43. Schneider, R. W. 1984. Effects of non-pathogenic strains of Fusarium oxysporum on celery root infection by $F$. oxysporum f. sp. apii and a novel use of the Lineweaver-Burk double reciprocal plot technique. Phytopathology 74:646-653.

44. Schouten, H. G. 1987. A revision of Billing's potential doublings table for fire blight prediction. Neth. J. Plant Pathol. 93:55-60.

45. Shaffer, W. H., and Goodman, R. H. 1962. Progression in vivo, rate of growth in vitro, and resistance to streptomycin, as indices of virulence of Erwinia amylovora. Phytopathology 52:1201-1207.

46. Shaner, G., Stromberg, E. L., Lacy, G. H., Barker, K. R., and Pirone, T. P. 1992. Nomenclature and concepts of pathogenicity and virulence. Annu. Rev. Phytopathol. 30:47-66.

47. Smith, K. P., Handelsman, J., and Goodman, R. M. 1997. Modeling doseresponse relationships in biological control: Partitioning host responses to the pathogen and biocontrol agent. Phytopathology 87:720-729.

48. Tharaud, M., Menggad, M., Paulin, J. P., and Laurent, J. 1994. Virulence, growth and surface characteristics of Erwinia amylovora mutants with altered pathogenicity. Microbiology 140:659-669.

49. Thomas, S. R., and Elkinton, J. S. 2004. Pathogenicity and virulence. J. Invertebr. Pathol. 85:146-151.

50. Thomas, T. M., and Jones, A. L. 1992. Severity of fire blight on apple cultivars in Michigan. Plant Dis. 76:1049-1052.

51. Van der Plank, J. E. 1975. Principles of Plant Infection. Academic Press, New York.

52. van der Zwet, T. 2002. Present worldwide distribution of fire blight. Acta Hortic. 590:33-34.

53. van der Zwet, T., and Keil, H. L. 1979. Fire blight, a bacterial disease of rosaceous plants. U.S. Dep. Agric. Agric. Handb. 510. Science and Education Administration, U.S. Dep. Agric., Washington, DC.

54. Vanneste, J. L. 1996. Honey bees and epiphytic bacteria to control fire blight, a bacterial disease of apple and pear. Biocontrol News Inf. 17:6778

55. Vanneste, J. (ed.) 2000. Fire Blight: The Disease and Its Causative Agent Erwinia amylovora. CABI Publishing, New York.

56. Wilson, M., Epton, H. A. S., and Sigee, D. C. 1992. Biological control of fire blight of hawthorn (Crataegus monogyna) with fluorescent Pseudomonas spp. under protected conditions. J. Phytopathol. 136:16-26. 